\title{
Issues of photovoltaic installation size choice for a hard coal mine
}

\author{
Sylwester Kaczmarzewski ${ }^{1}$, Piotr Olczak ${ }^{1 *}$, and Artur Halbina ${ }^{2}$ \\ ${ }^{1}$ Mineral and Energy Economy Research Institute, Polish Academy of Sciences, 7A Wybickiego St., \\ 31-261 Cracow, Poland \\ ${ }^{2}$ AGH University of Science and Technology, 30 Mickiewicza Ave., 30-059 Cracow, Poland
}

\begin{abstract}
Poland is the leader in hard coal mining in the European Union and in generation of electricity on this basis, it is related also to low generation of energy from renewable energy sources, in particular photovoltaic installations. The paper analyses the potential of PV installations application for the needs of a selected hard coal mine from the Upper Silesian Coal Basin. Using the hourly data on its electricity consumption in 2018 various sizes of PV installations were selected, a simple payback period was calculated as well as the percentage of energy from the installation use for the current mine operations. It has been shown that in the case of a mine, having available $20 \mathrm{MW}$ of ordered power and average consumption of approx. $14 \mathrm{MW}$, an installation of $20 \mathrm{MWp}$ rating covers approx. $15 \%$ of the electricity demand per year, while for 1 o'clock p.m., i.e. the hour at which most frequently the peak consumption occurred, the share in electricity demand coverage by the PV installation of this power on average amounts to approx. $50 \%$ per year.
\end{abstract}

\section{Introduction}

Poland is the biggest hard coal producer in Europe. In 2018 the volume of hard coal output was 63.4 million $\mathrm{Mg}$ [1], of which 51.3 million $\mathrm{Mg}$ was the steam coal [2]. However, the size of hard coal output in Poland has been showing a downward trend for years. Because of a slump in prices on the world hard coal markets, in the light of difficult market conditions in the years $2014-2016$, the hard coal mining sector in Poland was subject to restructuring and to production costs optimisation to recover competitiveness. Because of a significant share, in the costs by type structure, of growing electricity prices and of payroll, further cost optimisation is visible and also a decline of steam coal output in Poland. At the same time the growing economy and an increase in the air conditioning equipment use contribute to the increase in the electricity consumption in recent years [3, 4]. In 2018 the electricity consumption in Poland reached a historical maximum of $170.9 \mathrm{TWh}$, which means a growth of $10 \%$ as against the 2008 figures and of 23\% against 1998 [4]. Decisive majority of electricity in Poland originates from coal-fired power plants. In 2018 the share of conventional power industry based on hard coal was $49.86 \%$, while lignite was the second fuel, which share in the national energy mix was $29.7 \%$ [4].

\footnotetext{
* Corresponding author: piotrolczak@hotmail.com
} 
Despite the fact that the domestic power industry in Poland is based on fossil fuels, because of the adopted European Union climate policy Poland has the obligation to implement the assumed plans of $\mathrm{CO}_{2}$ emission reduction. Provisions of so-called Winter Package and of directives related to energy efficiency and to renewable energy sources anticipate introduction of changes in the power market functioning and in reducing the $\mathrm{CO}_{2}$ emissivity to a level of $550 \mathrm{~g} / \mathrm{kWh}$ for power plants allowed to use the power market, which practically eliminates the coal-fired power industry [5]. It is considered that rich resources of energy raw materials in Poland can and should be commercially used, because the use of domestic coal resources is crucial to retain the energy security of the country. Because of specific conditions of Polish power sector no radical abandoning of coal-fired power industry is anticipated during the next 30 years [5]. In the context of declining supply of hard coal from domestic deposits such forecasts mean growing energy and raw materials dependence of Poland, because in 2018 once more an increase in hard coal imports was recorded, which reached its historical maximum of 19.7 million $\mathrm{Mg}, 68 \%$ of which was the coal from Russia [6]. No premises exist to reverse or stop this trend [5, 7]. To cover the growing energy demand and to meet the EU climate requirements it will be necessary to invest in the generation and grid sector. Investment projects in the power sector in Poland include primarily construction of a few new coal-fired units carried out in the years 20172019, i.e. "Kozienice' (1085 MW), "Opole" (2x900 MW), and "Jaworzno III" (910 MW) $[3,5,8-10]$. Because of the age structure of boilers and turbines, many of which are older than 40 years and achieve efficiency slightly above 30\%, it is necessary to invest in modernisation of class $200 \mathrm{MW}$ facilities operating now [3]. To meet the postulates resulting from the EU IED directive of 2010 and from the regulation of the Minister of Environment, part of coal-fired units was already modernised. However, in accordance with political directions presented by the Government, due to low efficiency and the necessity to maintain the required emissivity level, a programme of comprehensive modernisation of units was announced, carried out by the National Centre for Research and Development, which assumes adapting sub-critical class 200 MWe units to the imposed by BAT (Best Available Techniques) conclusions ever stricter requirements of permissible emission level by 2021 [3]. Modernised units would have to achieve efficiency by $2-3 \%$ lower as compared with new units with efficiency of approx. $45 \%$. This modernisation would mean the use of coal for another 20 years [5].

Companies of the power-consuming industry (including entities from the hard coal mining sector) are among key electricity consumers, using in total approx. $20 \mathrm{TWh}$ of electricity per year [11]. According to the official statistics [12] available for the year of 2017 the unit electricity consumption per each tonne of hard coal was $53 \mathrm{kWh}$, hence the electricity consumption in hard coal mines in Poland is approx. 3.5 TWh per year, which constitutes approx. $2.1 \%$ of the domestic consumption [4]. Despite the fact that an investment project of a mine in renewable energy sources could seem irrational due to strong links of the hard coal mining sector with the commercial power sector in Poland, the escalation of steam coal deficit on the national market, observed since 2008, is not a premise of concerns about the sales of domestic product for the commercial power sector needs [1, 13, 14]. Moreover, from 2016 the reverse of international electricity exchange balance is noticeable in Poland (from an exporter to an importer). Despite the fact that higher electricity consumption in Poland falls for the autumn-winter season [4], incidents of electricity deficit in the national power system are especially noticeable during the summertime. This is related to reduction of electricity generation in co-generation CHPs due to reduced demand for heat, limited to ensuring hot water in the distribution network. However, the power losses in coal-fired units are the key factor of the deficit, resulting from the number of emergency repairs - increasing with their age - and more and more widespread use of air-conditioning in spring and in summertime. 
The influence of observed climate changes is also significant. The severe in recent years record high air temperatures and long lasting droughts contribute not only to problems with coal-fired units cooling and their emergency shut-downs, but also to a performance decrease of RES functioning in Polish power grid [15]. In the national energy mix wind turbines have the highest RES share, however, during windless hot days the amount of electricity generated by them drastically goes down. The lowering of river water levels causes reduction of hydroelectric power stations capacity. Instead, the share of photovoltaics, for which the sunny summer days constitute the most favourable operating conditions, remains still marginal in the structure of electricity sources in Poland. Because of formal and legal conditions resulting from provisions of the adopted EU energy policy, imposing on Poland the obligation to reach in 2020 15\% share of RES in the energy mix and due to the increase in electricity prices resulting from the introduction of emission charges for conventional power sector, the interest in the PV technology has been sharply increasing [16-18]. The power installed in photovoltaic sources in Poland at the end of 2018 was approx. 500 MW, and in May 2019 it exceeded 700 MW. According to expert opinions the cumulative capacity of PV installations in Poland will reach $1.5 \mathrm{GW}$ at the end of 2019 [19].

Because of climate warming the incidents of record power demand in the national power system and of record electricity imports within inter-operator inter-systemic exchange can repeat. Then a relatively minor breakdown of one power station can upset the energy security of the country, including that of key entities of power-consuming industry. Historically record demands for electricity during the summer time occurred during the morning rush hours due to mass utilisation of air-conditioning units, which in the light of decreased efficiency of power units cooling resulted in registered cases of electricity generation capacity limitation in conventional power stations.

Because of specific nature of the extraction process, including safety of employed people, a hard coal mine must have a guarantee of energy security. Crucial processes of mining plant maintenance, such as ventilation or drainage, cannot be stopped even in the case of energy consumption limitations introduced by the national power grid operator. At the same time, the possession of an own photovoltaic installation can change the level of energy stability of the mine. On a hot day, in the case of limitations introduction by the grid operator, a photovoltaic installation, depending on the designed capacity and the level of mine electricity demand, can provide the mine with power for the needs to maintain continuity of the technological process above the minimum ensured by the grid operator. Taking into consideration the increasing problem of coal deficit on the domestic market and beaten air temperature records as well as provisions of the EU climate policy, strong arguments exist to get interested in the issue of optimum choice of a photovoltaic installation size in a hard coal mine.

The paper is aimed at choosing a photovoltaic installation for an example of Polish hard coal mine. Electricity is a significant component of the total operating costs of companies from the mining sector, therefore the economy of the analysed solution decides about the legitimacy of the raised issue considerations (apart from environmental issues). According to sources [20] even approx. $40 \%$ of electricity in an underground mine is used by the ventilation system equipment. Taking into account that the coal mining moves to deeper and deeper existing deposit parts, the energy outlays related to the ventilation (and cooling) of mine workings become substantially important, at the same time becoming a significant area to look for potential improvement in the energy efficiency [21]. The price of electricity purchase by mines is approx. $116 \mathrm{EUR} / \mathrm{MWh}$ together with the distribution fee, and the variability of prices on the next day market in 2018 is illustrated in Fig. 1. 


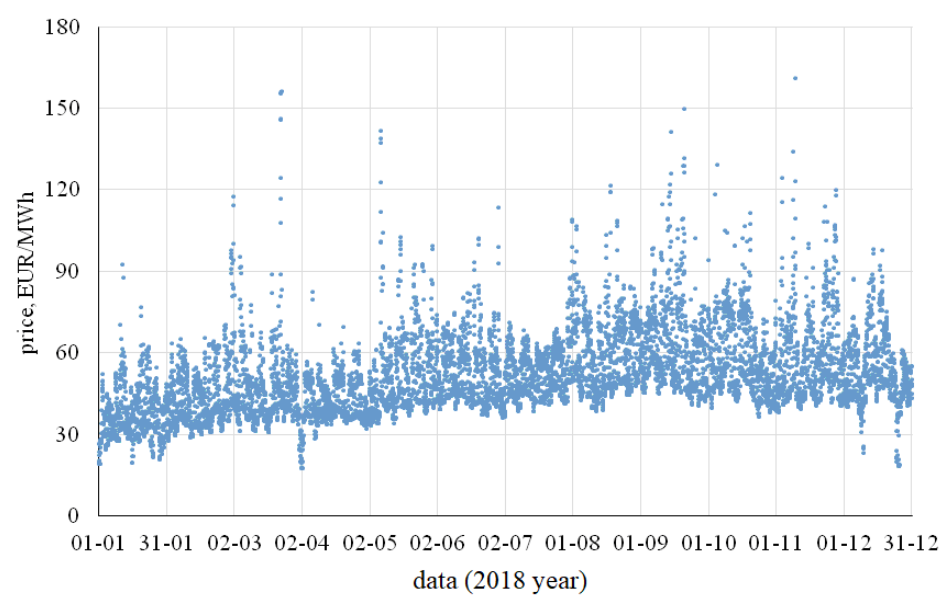

Fig. 1. Electricity prices on the next day market in 2018. Source: own study based on [22].

At the same time, in the case of electricity overgeneration by the photovoltaic installation, the sales price ranges from approx. 35 to 70 EUR/MWh. It should be emphasised, that the case considered for the paper needs represents a system free of grants and subsidies, which is of considerable importance for the investment's economy. In a grant system the level of capital expenditure would be reduced due to a grant given at the stage of its construction. However, support systems for such investment projects existing in 2019 substantially limit the access of big enterprises (including mines) to such grants. Instead, in the case of a subsidy system the installation owner would obtain a subsidy to the energy sales price referred to as the "green" energy.

Another aspect affecting a photovoltaic installation economy is the area for PV panels construction. Depending on the solution scale a photovoltaic installation can exist as socalled "microinstallation" (e.g. an investment project of up to $10 \mathrm{~kW}$ capacity for a household needs placed on a house roof [16]or in a form of large-area PV system (e.g. PV installation in an Australian copper and gold ore mine De Grussa of 10.6 MW power consisting of $34.080 \mathrm{PV}$ panels installed on the area of more than $200.000 \mathrm{~m}^{2}$, working in an off-grid mode $[23,24]$ ). Obviously the construction of a $10 \mathrm{MW}$ installation is related to relatively high capital expenditure, connected both to the installation itself and to the ground for its construction. The cost of a $1 \mathrm{MW}$ PV installation in Poland is approx. EUR $0.9-1.4$ million, and it requires an area of approx. $20.000 \mathrm{~m}^{2}$. Whereas an average price of $1 \mathrm{~m}^{2}$ of real property designed for industrial development in Silesian Voivodeship in 2017 was EUR 13.3 [12]. The considered construction of installation on the site of a hard coal mine has, however, an additional justification in reducing the necessity to buy the dedicated area. Depending on the utilisation potential of the power supplied by a photovoltaic installation and its planned size it can be constructed e.g. on the roof of Coal Preparation Plant or in the area of wasteland intended for reclamation, e.g. mine waste heap, which practically could not be sold. So it is possible to assume, that in fact the investor does not bear the cost of real property purchase.

Because of the fact that decisive majority of steam coal in Poland originates from collieries mining within the Upper Silesian Coal Basin, the location of Katowice - the biggest Basin city - was taken in further considerations. Taking into account legislative conditions presented earlier herein, the suggested direction should be considered favourable to meet the EU climate policy assumptions. At the same time this action creates a margin of mine independence against the predicted further increase in electricity prices, especially due to the fact that the LCOE (Levelised Cost of Electricity) of photovoltaics noticeably 
goes down [25]. Now there are no premises to go away from the coal-fired power sector, and at the same time to finish the hard coal mining in Poland during the nearest 30 years [5], but in the case of a drastic change of this scenario, the PV installation planned for the needs of an existing mining plant at standard life of approx. 25 years can successfully supply the equipment of mine waters drainage and treatment station, reducing the costs incurred after the end of mining. Because of the above the main objective of the paper is to study the solution profitability considering characteristics of daily electricity consumption changes and developing a hypothetical scenario of a PV installation application under conditions of a hard coal mine in Poland.

\section{Potential of photovoltaics in Poland}

Poland features geographical and climate conditions similar to the northern and central part of Germany, the world leader in the field of installed PV installation power, which should have a stimulating effect on undertaking investment projects in photovoltaics in Poland. The maximum quantity of insolation available on a fixed area is approx. $1150 \mathrm{kWh} / \mathrm{year} / \mathrm{m}^{2}$ [26]. The analysis of insolation in the territory of Poland has shown that there are no significant differences in the insolation between Katowice and the other cities of the Silesian conurbation [27]. For the selected city the maximum insolation occurs for a plane inclined southwards. The angle, for which the insolation value is the highest, is approx. $30^{\circ}$ (Fig. 2), but for further calculations - due to practical reasons, as well as of the impact of panel self-cleaning both from snow and from dust - an angle of $45^{\circ}$ was selected, for which the annual insolation value is lower by $1 \mathrm{kWh} / \mathrm{m}^{2}$ than for the angle of $30^{\circ}$ and amounts to $1098 \mathrm{kWh} /\left(\mathrm{m}^{2} \cdot\right.$ year $)$.

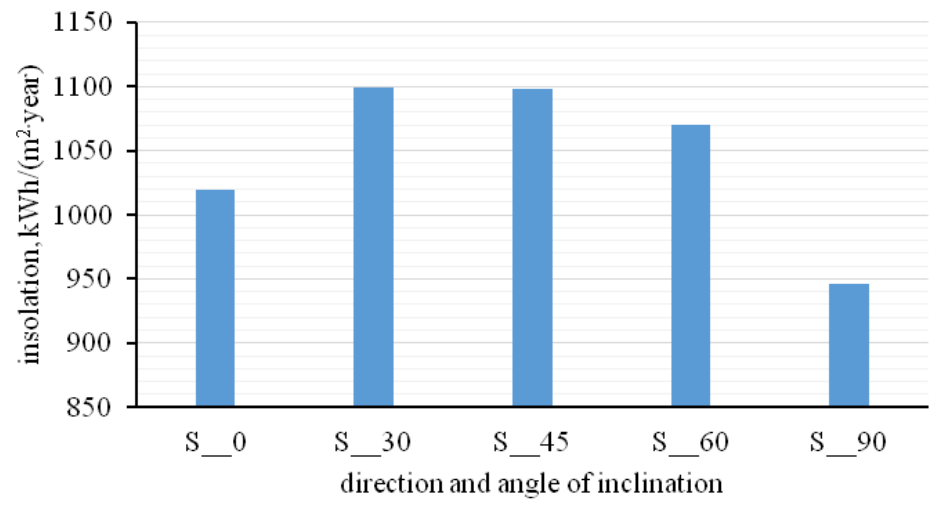

Fig. 2. Insolation for Katowice, southern direction - Typical Reference Year. Source: own study based on [27].

\section{Calculations and results}

Photovoltaic panels parameters determined according to STC (Standard Test Conditions) standards were used in calculations. The power of a photovoltaic module, its efficiency, and other technical parameters depend strongly on weather conditions, under which it operates. STC conditions are a set of parameters enabling to compare photovoltaic panels between themselves, comprising values of solar radiation intensity $\left(1000 \mathrm{~W} / \mathrm{m}^{2}\right)$, temperature of photovoltaic cells of the illuminated PV module $\left(25^{\circ} \mathrm{C}\right)$, atmosphere thickness $(1.5)$, and 
wind velocity $(1 \mathrm{~m} / \mathrm{s})$. The panels productivity was calculated according to the assumptions made. The paper has not considered the issue of panels efficiency, using the power expressed in Wp (Watt peak). Also the efficiency dependence on temperature or other external factors, such as the type of substrate/subsoil for panels construction has not been analysed, because the impact of such factors was arbitrarily considered insignificant for general issues of installation choice. Naturally, the above factors influence the panels purchase price and the total investment cost, therefore in the case of designing a specific installation the optimisation may be carried out, e.g. in terms of savings related to the land purchase for the installation in the case of panels manufactured according to the highest efficiency technology, due to which the required area will be smaller.

The collected data on the electricity consumption in the mine and on the insolation, for every hour during a year, were used in the calculations - Fig. 3.

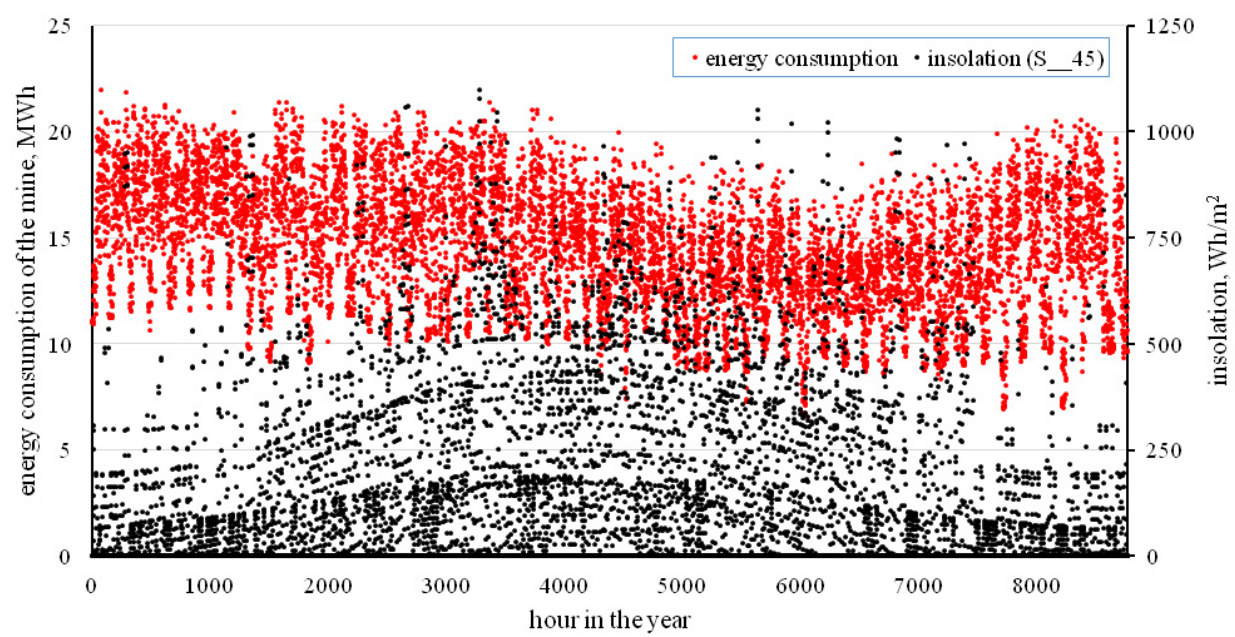

Fig. 3. The energy consumption in the mine and the insolation for the plane inclined at an angle of $45^{\circ}$ and directed southwards. Source: own study based on [27].

The data on energy consumption at every hour in 2018 were compared with the insolation data. For various assumed installation sizes of $5,10,15, \ldots, 50 \mathrm{MWp}$ the generated energy was calculated, taking into account efficiency, and broken down into used on a current basis and sold to the grid. For the installation of $5 \mathrm{MWp}$ power the energy generation did not exceed the consumption. Then an economic analysis was carried out, using the following assumptions:

- Inverter and transmission efficiency - 90\%;

- Price of electricity sold - 46.5 EUR/MWh;

- Price of electricity purchased from the grid - 116.3 EUR/MWh, including the distribution fee;

- The investment cost - EUR 1.16 million per MWp, effects of scale related to the investment were neglected;

- Below radiation intensity of $50 \mathrm{~W} / \mathrm{m}^{2}$ panels do not generate energy;

- Cost of the land for installation construction was not considered.

Moreover, an assumption was made, that the increase in the electricity price will be equal to the discount rate.

Based on the above assumptions the dependence of installation simple payback time (SPBT) on the installation size was determined and presented on the graph (Fig. 4). 


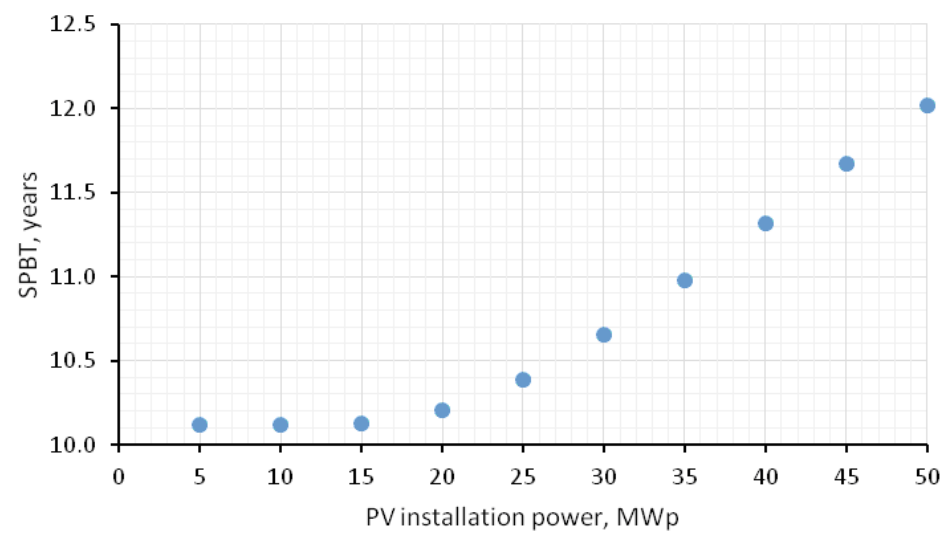

Fig. 4. Simple payback time of PV installation for the analysed mine. Source: own study.

For powers of 5 and $10 \mathrm{MWp}$ the simple payback time does not depend on the installation size and is approx. 10.1 year. For powers exceeding $25 \mathrm{MWp}$ a clear increasing relationship appears.

Then the PV installation generation shares in the energy demand covered on a current basis were determined - Fig. 5 .

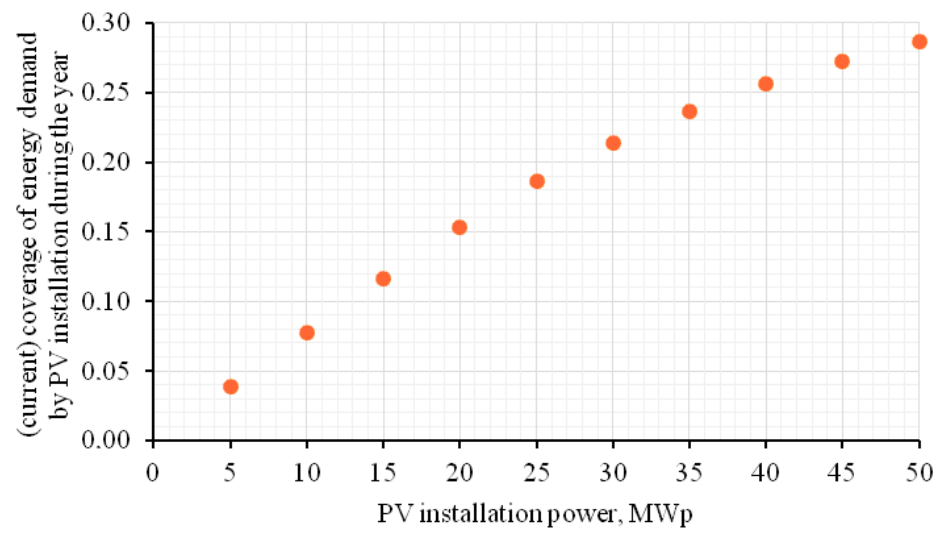

Fig. 5. The ratio of the share of energy generated by the PV installation and used on a current basis in the mine to the total energy demand on the annual scale versus the power of planned PV installation. Source: own study.

The share of energy demand coverage by the photovoltaic installation, even for a power of $50 \mathrm{MWp}$, that is 2.5 times higher than the power ordered in the mine reaches no more than $29 \%$. Such a level is conditioned by a relatively high energy consumption in the mine at night as compared with the daytime and in winter as compared with the summer period. Therefore the share for 1 o'clock p.m., i.e. the hour at which most frequently the peak energy consumption occurred at the KSE (National Power Grid) [28] was analysed, the results are presented on the graph - Fig. 6. 


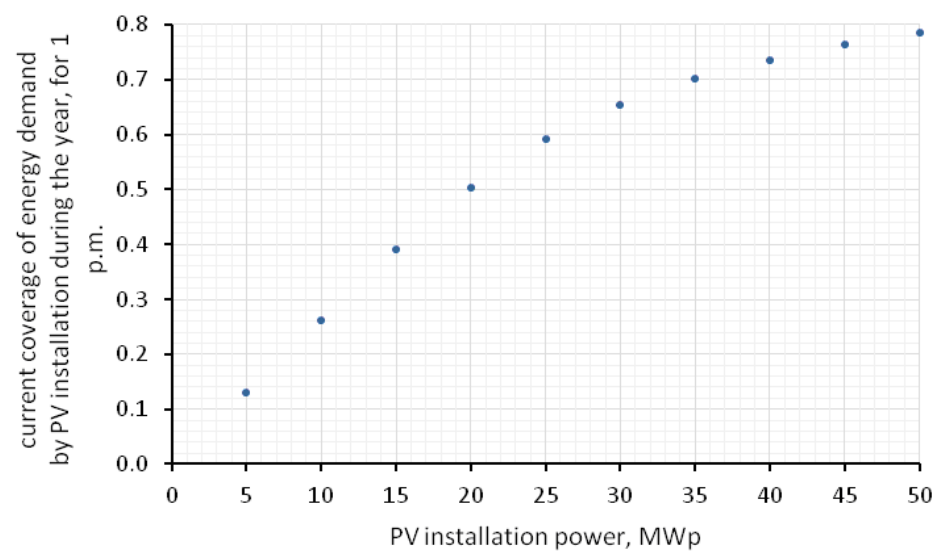

Fig. 6. The ratio of the share of energy generated by the PV installation and used on a current basis in the mine to the total energy demand on the annual scale for 1 p.m. versus the power of planned PV installation. Source: own study.

\section{Conclusions}

Despite a clearly outlined direction of EU energy policy decarbonisation, the current energy policy of Poland does not predict radical abandoning of the coal-fired power sector. The adopted EU legislation obligates the EU member states to reduce the $\mathrm{CO}_{2}$ emission, therefore - considering the energy security of the country as the priority - Poland takes actions to increase the energy efficiency sticking to the economic use of domestic hard coal resources. Such actions comprise primarily investment expenditures on the construction of new high-efficiency coal-fired power units and modernisation of the existing generation units and of the power grid, which create long-term prospects also for the mining sector operation in Poland.

The EU restrictions on the $\mathrm{CO}_{2}$ emission resulting in the growing prices of energy from conventional power plants mean the necessity to increase the share of renewable energy sources in the national energy mix. However, because of climate conditions, the conventional power industry - modernised and capable of dynamic load changes depending on the demand - will remain the basic source of electricity in Poland.

An increase in power-consuming industry enterprises interest in the RES issues results first of all from economic reasons. The solution presented in the paper consists in the electricity generation during the daytime, hence in the period of highest energy purchase prices resulting from binding tariff conditions. Moreover, the use of a photovoltaic installation creates some margin of energy stability, because incidents of the energy consumption limitation during record air temperatures occur in our climate on cloudless and windless days (a low level of energy generation in wind turbines), which are the best conditions for PV installations operation among renewable energy sources used in Poland.

The carried out analysis has shown that in the case of the considered mine there is no relationship between the simple payback time and the installation size for installations with power ranging from 5 to $15 \mathrm{MWp}$. For a power exceeding $15 \mathrm{MWp}$ an increasing relationship is visible. The coverage of energy demand by the photovoltaic installation features relatively low values, not exceeding $29 \%$ even in the case of installation power 2.5 times higher than the mine ordered power. This is conditioned primarily by a high energy consumption at night, resulting from the tariff plan in force, and also in winter due to increased intensity of work as compared with the summer holiday period. The analysis of energy demand coverage share by the PV installation for 1 p.m., i.e. the hour at which most 
frequently the peak energy consumption at the KSE(NPG) appears, has shown that the installation share amounts to $79 \%$ per annum. At the same time a directly proportional relation between the PV installation size and the share of energy demand coverage above a power of $20 \mathrm{MWp}$ of the installation changes its nature to logarithmic.

Summing up, the results of analysis show that the choice of PV installation size not exceeding the value of ordered power is the optimal one, at simultaneous consideration of increased scope of work carried out at the mine at hours around noon, to change the current characteristic of daily energy consumption. The daily consumption depends now inter alia on the electricity prices, which are lower at night. The need to maximise the coverage of own demand and the reduction of sold energy amount results from low sales prices of the generated energy surplus. The optimisation of the installation potential utilisation is justified additionally by a risk of significant decline of electricity prices at moments of peak energy generation from on-grid photovoltaic installations, which amounts can suddenly increase in the future. The scale of the problem will depend on the relationship between the number of PV installations commissioned in the future and cooling installations consuming electricity during the periods of high values of solar radiation intensity.

This research was supported by Mineral and Energy Economy Research Institute of the Polish Academy of Sciences.

\section{References}

1. Polski Rynek Węgla. (2019). Produkcja węgla kamiennego ogółem - miesiace: I 2018 - XII 2018. [online]. Available at: https://polskirynekwegla.pl/raport-dynamiczny/produkcja-weglakamiennego-ogolem-miesiace

2. Jastrzębska Spółka Węglowa S.A. (2019). Sprawozdanie zarządu z działalności Jastrzębskiej Spótki Węglowej S.A. oraz Grupy Kapitatowej Jastrzębskiej Spółki Węglowej S.A. JastrzebieZdroj.

3. Matan, K., \& Ziółkowska, K. (2018). Pozyskanie innowacyjnych metod modernizacji bloków energetycznych przy wykorzystaniu modelu zamówień przedkomercyjnych. Program "Bloki 200+" realizowany przez Narodowe Centrum Badań i Rozwoju. The Bulletin of the Mineral and Energy Economy Research Institute of the Polish Academy of Sciences, (102), 261-276.

4. Polskie Sieci Elektroenergetyczne (2018). Produkcja $i$ zużycie energii elektrycznej $w$ elektrowniach krajowych. Raport 2018 KSE", Warsaw.

5. Gawlik, L., \& Mokrzycki, E. (2017). Paliwa kopalne w krajowej energetyce - problemy i wyzwania. Polityka Energetyczna - Energy policy journal, 20(4), 6-26.

6. Polish Press Agency. (2019). Import węgla w 2018 r. wzróst o 53 proc. rdr-NBP. [online]. Available at: http://biznesalert.pl/nbp-import-wegla-w-2018-roku-wzrosl-o-53-procent-rok-doroku/

7. Gawlik, L. (2018) The Polish power industry in energy transformation process. Mineral Economics, (31), 229-237.

8. Agencja Rynku Energii. (2018). Enea podsumowała rok pracy bloku B11 w Elektrowni Kozienice. [online]. Available at: http://www.cire.pl/item,173590,1,1,2,0,329442,0,eneapodsumowala-rok-pracy-bloku-b11-w-elektrowni--kozienice.html\#komentarz

9. PGE. (2019). PGE: nowy blok nr 5 w Elektrowni Opole przekazany do eksploatacji. [online]. Available at: https:/www.gkpge.pl/Biuro-Prasowe/Komunikaty-prasowe/korporacyjne/pgenowy-blok-nr-5-w-elektrowni-opole-przekazany-do-eksploatacji

10. Tauron Polska Energia SA. (2019). Skonsolidowany raport roczny Grupy Kapitałowej Tauron Polska Energia S.A. za 2018 r. [online]. Available at: https://www.tauron.pl/-/media/offerdocuments/tauron/raporty-okresowe/2018/roczny-2018/skonsolidowany-raport-roczny-grupykapitaowej-tauron-polska-energia-sa-za-2018-r.ashx 
11. Polish Press Agency. (2018). Przemyst energochłonny potrzebuje warunków do rozwoju $i$ http://centrumprasowe.pap.pl/cp/pl/news/info/119966,25,przemysl-energochlonny-potrzebujewarunkow-do-rozwoju-i-inwestowania

12. Statistics Poland. (2018). Statistical Yearbook of Industry - Poland. W Energy statistics and materials management. Statistics Poland, 368-400.

13. The Polish Geological Institute - National Research Institute. (2017). Import i eksport węgla kamiennego w Polsce. [online]. Available at: https://www.pgi.gov.pl/psg-1/psg-2/informacja-iszkolenia/wiadomosci-surowcowe/10419-import-i-eksport-wegla-kaminnego-w-polsce.html

14. Mineral and Energy Economy Research Institute of the Polish Academy of Sciences. (2018). https://min-pan.krakow.pl/wp-content/uploads/2018/07/Raport-2017 END.pdf

15. Polskie Sieci Elektroenergetyczne. (2019). Rekord zapotrzebowania na moc w okresie letnim. [online]. Available at: https://www.pse.pl/biuro-prasowe/aktualnosci//asset_publisher/fwWgbbtxcZUt/content/rekord-zapotrzebowania-na-moc-w-kse-w-okresieletnim

16. Institute for Renewable Energy. (2019). Raport "Rynek fotowoltaiki w Polsce 2019”. Warsaw: Institute for Renewable Energy.

17. Agencja Rynku Energii. (2019). PGG planuje zwiększenie wykorzystania metanu i chce inwestować fotowoltaikę. [online]. Available at: https://www.cire.pl/item, 177725,1,0,0,0,0,0,pgg-planuje-zwiekszenie-wykorzystania-metanu-ichce-inwestowac-w-fotowoltaike.html

18. Polish Press Agency (2019). Zielona energia będzie wykorzystywana w produkcji miedzi. KGHM zdradził szczegóły. [online]. Available at: https://www.pap.pl/centrumprasowe/475697\%2Czielona-energia-bedzie-wykorzystana-w-produkcji-miedzi-kghm-zdradzil

19. Institute for Renewable Energy. (2019). Raport “Rynek fotowoltaiki w Polsce 2018”. Warsaw: Institute for Renewable Energy.

20. Holmberg, K., Kivikytö-Reponen, P., Härkisaari, P., Valtonen, K., \& Erdemir, A. (2017). Global energy consumption due to friction and wear in the mining industry. Tribology International, (115), 116-139. https://doi.org/10.1016/j.triboint.2017.05.010

21. Kicki, J., \& Jeziorowska, D. (2015). Wybrane aspekty zarządzania efektywnością energetyczną w przedsiębiorstwach. Przegląd Górniczy, (8), 30-34.

22. TGE. (2018). Electricity Day-Ahead Market (DAM). [online]. Available at: https://tge.pl/electricity-dam

23. Choi, Y., \& Song, J. (2017). Review of photovoltaic and wind power systems utilized in the mining industry. Renewable and Sustainable Energy Reviews, (75), 1386-1391. https://doi.org/10.1016/j.rser.2016.11.127

24. Sandfire Resources NL. (2019). Solar power project. [online]. Available at: https://www.sandfire.com.au/site/operations/degrussa/solar-power-project

25. Zharan, K., \& Bongaerts, J.C. (2017). Decision-making on the integration of renewable energy in the mining industry: A case studies analysis, a cost analysis and a SWOT analysis. Journal of Sustainable Mining, 16(4), 162-170. https://doi.org/10.1016/j.jsm.2017.11.004

26. Pepłowska, M., \& Olczak, P. (2018), Problematyka doboru kąta posadowienia paneli fotowoltaicznych $\mathrm{z}$ uwzględnieniem profilu zapotrzebowania na energię. The Bulletin of The Mineral and Energy Economy Research Institute of the Polish Academy of Sciences, (102), 91100.

27. Ministry of Investment and Economic Development. (2019) Typowe lata meteorologiczne $i$ statystyczne dane klimatyczne. Dane do obliczeń energetycznych budynków. [online]. Available at: https://www.gov.pl/web/inwestycje-rozwoj/dane-do-obliczen-energetycznych-budynkow

28. KSE (NPG). (2019). Raport 2018 KSE. [online]. Available at: https://www.pse.pl/danesystemowe/funkcjonowanie-rb/raporty-roczne-z-funkcjonowania-kse-za-rok/raporty-za-rok-2018 